\title{
The Impact of Business Ownership Change on Employee Relations: Buy-outs in the UK and the Netherlands
}

\author{
Hans Bruining, Paul Boselie, Mike Wright and Nicolas Bacon
}

\begin{tabular}{|l|l|}
\hline \multicolumn{2}{|l|}{ ERIM REPORT SERIES RESEARCH IN MANAGEMENT } \\
\hline ERIM Report Series reference number & ERS-2004-021-ORG \\
\hline Publication & March 2004 \\
\hline Number of pages & 41 \\
\hline Email address corresponding author & bruining@few.eur.nl \\
\hline Address & Erasmus Research Institute of Management (ERIM) \\
& Rotterdam School of Management / Rotterdam School of Economics \\
& Erasmus Universiteit Rotterdam \\
& P.O.Box 1738 \\
& 3000 DR Rotterdam, The Netherlands \\
& Phone: +31 10 408 1182 \\
& Fax: $\quad+31104089640$ \\
& Email: info@erim.eur.nl \\
& Internet: $\quad$ www.erim.eur.nl \\
\hline
\end{tabular}

Bibliographic data and classifications of all the ERIM reports are also available on the ERIM website: www.erim.eur.nl 


\title{
ERASMUS RESEARCH INSTITUTE OF MANAGEMENT
}

\author{
REPORT SERIES \\ RESEARCH IN MANAGEMENT
}

\begin{tabular}{|c|c|c|}
\hline \multicolumn{3}{|c|}{ BIBLIOGRAPHIC DATA AND CLASSIFICATIONS } \\
\hline Abstract & \multicolumn{2}{|c|}{$\begin{array}{l}\text { A buy-out is a fundamental change in the structure of ownership that may affect the way } \\
\text { employee relations develop within an organisation. Little is known about the impact of buyouts } \\
\text { upon employee relations. This paper aims to address this gap. We focus on two main } \\
\text { questions. First, what are the effects of a buy-out on employee relations in an organisation? } \\
\text { Second, does the national institutional context affect the impact of buy-outs on employee } \\
\text { relations? The paper reports changes to employee relations in buy-outs in the contrasting } \\
\text { institutional environments of the UK and the Netherlands. Overall, we find that buy-outs } \\
\text { positively affect HR practices with increases in training, employee involvement, the number of } \\
\text { employees and pay levels. The positive effects appear to be significantly stronger in a less } \\
\text { institutionalised environment like the UK than the more institutionalised environment of the } \\
\text { Netherlands. Buy-outs raised HRM practices in the UK to a level closer although still below that } \\
\text { of Dutch buy-outs. }\end{array}$} \\
\hline \multirow{3}{*}{$\begin{array}{l}\text { Library of Congress } \\
\text { Classification } \\
\text { (LCC) }\end{array}$} & $5001-6182$ & Business \\
\hline & $5546-5548.6$ & Office Organization and Management \\
\hline & HD 58.8 & Organizational change \\
\hline \multirow{3}{*}{$\begin{array}{l}\text { Journal of Economic } \\
\text { Literature } \\
\text { (JEL) }\end{array}$} & M & Business Administration and Business Economics \\
\hline & $\begin{array}{l}\text { M } 10 \\
\mathrm{~L} 2\end{array}$ & $\begin{array}{l}\text { Business Administration: general } \\
\text { Firm Objectives, Organization and Behaviour }\end{array}$ \\
\hline & L 29 & Firm Objectives, Organisation and Behavior, other \\
\hline \multirow{3}{*}{$\begin{array}{l}\text { European Business Schools } \\
\text { Library Group } \\
\text { (EBSLG) }\end{array}$} & $85 \mathrm{~A}$ & Business General \\
\hline & $\begin{array}{l}100 B \\
240 B\end{array}$ & $\begin{array}{l}\text { Organization Theory (general) } \\
\text { Information Systems Management }\end{array}$ \\
\hline & $270 \mathrm{~L}$ & Management buy-outs \\
\hline \multicolumn{3}{|c|}{ Gemeenschappelijke Onderwerpsontsluiting (GOO) } \\
\hline \multirow[t]{3}{*}{ Classification G0O } & 85.00 & Bedrijfskunde, Organisatiekunde: algemeen \\
\hline & $\begin{array}{l}85.05 \\
85.08\end{array}$ & $\begin{array}{l}\text { Management organisatie: algemeen } \\
\text { Organisatiesociologie, organisatiepsychologie }\end{array}$ \\
\hline & 85.10 & Strategische beleid \\
\hline \multirow[t]{3}{*}{ Keywords GOO } & \multicolumn{2}{|c|}{ Bedrijfskunde / Bedrijfseconomie } \\
\hline & \multicolumn{2}{|c|}{ Organisatieleer, informatietechnologie, prestatiebeoordeling } \\
\hline & \multicolumn{2}{|c|}{ Buy-outs, arbeidsverhoudingen, personeelsbeleid, institutionalisme } \\
\hline Free keywords & \multicolumn{2}{|c|}{ Buy-outs; employee relations; HRM; agency theory; institutional theory; comparative analysis } \\
\hline
\end{tabular}




\title{
The Impact of Business Ownership Change on Employee Relations: \\ Buy-outs in the UK and the Netherlands
}

\author{
Hans Bruining and Paul Boselie \\ Erasmus University Rotterdam
}

Mike Wright and Nicolas Bacon

Nottingham University Business School

Corresponding author: Hans Bruining, Department of Business \& Organisation, Rotterdam School of Economics, Erasmus University, P.O. Box 1738, 3000 DR Rotterdam, The Netherlands H15-1, Phone (+31) 10 - 4081361 Fax: (+31) 10 - 4089169 Email: bruining@ few.eur.nl

Paul Boselie, Department of Business \& Organisation, Rotterdam School of Economics, Erasmus University, P.O. Box 1738, 3000 DR Rotterdam, The Netherlands H15-1, Phone (+31) 10 - 4082542 Fax: (+31) 10 - 408 9169 Email: boselie@few.eur.nl

Mike Wright, Centre for Management Buy-out Research, Nottingham University Business School, Jubilee Campus, Nottingham NG8 1BB, United Kingdom; E-mail: mike.wright@nottingham.ac.uk and Professor Rotating Chair Organisation Studies Erasmus University Rotterdam.

Nicolas Bacon, Nottingham University Business School, Jubilee Campus, Nottingham NG8 1BB, United Kingdom; Email: nicholas.bacon@ nottingham.ac.uk 


\title{
The Impact of Business Ownership Change on Employee Relations: \\ Buy-outs in the UK and the Netherlands
}

\begin{abstract}
A buy-out is a fundamental change in the structure of ownership that may affect the way employee relations develop within an organisation. Little is known about the impact of buyouts upon employee relations. This paper aims to address this gap. We focus on two main questions. First, what are the effects of a buy-out on employee relations in an organisation? Second, does the national institutional context affect the impact of buy-outs on employee relations? The paper reports changes to employee relations in buy-outs in the contrasting institutional environments of the UK and the Netherlands. Overall, we find that buy-outs positively affect HR practices with increases in training, employee involvement, the number of employees and pay levels. The positive effects appear to be significantly stronger in a less institutionalised environment like the UK than the more institutionalised environment of the Netherlands. Buy-outs raised HRM practices in the UK to a level closer although still below that of Dutch buy-outs.
\end{abstract}

Keywords Buy-outs; employee relations; HRM; agency theory; institutional theory; comparative analysis 


\section{Introduction}

Management buy-outs of companies or parts of organisations have become an important development in corporate governance over the past twenty years as a mechanism for rescuing troubled businesses. In the UK buy-outs have increased their importance as part of the broader changes occurring in business structure from an average of 306 per year in the 1980s, to an average of 610 buy-outs completed annually in the 1990s (CMBOR, 2002). In the Netherlands, buy-outs rose from an average of 29 per year in the 1980s to an average of 54 per year in the 1990s (CMBOR/Initiative Europe, 1991; CMBOR, 2003). Expressing the value of buy-out markets in the two countries as a percentage of GDP provides a means of comparing their level of development. On this basis, the value of UK buy-outs rose from approximately 0.5 per cent of GDP in 1990 to 2 per cent in 1999. The comparable figures for the Netherlands were 0.05 per cent in 1990 and 0.7 per cent in 1999. The UK had the highest number of buy-outs in Europe in 1999, while the Netherlands was ranked third.

The main aim of a buy-out is to improve organisational performance through ownership change creating new opportunities for strategic reorientation and restructuring of the firm (Thompson and Wright, 1995). This fundamental change in the structure of ownership may affect the way employee relations develop within an organisation (Pendleton, Wilson and Wright, 1998). Little is known about the impact of buy-outs upon employee relations. This paper aims to address this gap. We focus on two key questions. First, what are the effects of a buy-out on employee relations in an organisation? Second, does the national institutional context affect the impact of buy-outs on employee relations? The paper considers employee relation's issues in the contrasting institutional environments of the UK and the Netherlands. Theoretical insights from the field of human resource management and buy-outs are incorporated to study the effect of ownership change on employee relations in 190 firms. 
The structure of the paper is as follows. First, we define buy-outs in section 2 and suggest buy-outs provide an opportunity for managers to reassess and change employee relations using two different perspectives that may explain these changes: a cost reduction and an investment perspective. In section 3 we review the empirical literature relating to the impact of buy-outs on employee relations and contrast findings in UK and Dutch studies. Section 4 outlines the different institutional contexts in these two countries and presents an institutional perspective that may explain the findings. The methodology presented in section 5 is followed by a comparative analysis of the empirical data of 190 buy-outs in the UK and the Netherlands in section 6. In the final section we discuss the findings, the limitations of the study and draw some conclusions.

\section{Buy-outs and Employee Relations}

A management buy-out (MBO) involves members of the incumbent management team, backed by financial institutions acquiring a significant equity stake as individuals in order to control the company (Robbie and Wright, 1996). The former parent or private company owners are replaced by a 'fresh' coalition of new investors and owners/managers from inside and/or outside the company. They aim to improve organisational performance through restructuring, cost reduction, strategic reorientation, product development and innovation, or by using a combination of these measures. Sources of buy-outs vary, although most buy-outs result from the rationalisation of public firms and ownership succession in private firms. Other buy-outs emerge from privatisation and receivership. Embedded in these different buyout types there is considerable opportunity for change that we will explain below.

Prior UK research indicates that certain features of employee relations change while others remain constant after a buy-out. Two surveys conducted in the 1980s emphasized continuity, suggesting that management buy-outs resulted in changes, although relatively few 
in employee relations. Wright, Coyne and Lockley (1984) reported that just a few buy-outs involved a subsequent move towards de-recognizing trade unions because managers perceived unions 'as an essential means of communicating with the workforce'. A greater change was detected with respect to increases in the employment of part-time workers (Wright, Chiplin, Thompson and Robbie, 1990) and job losses following buy-outs (Wright and Coyne, 1985), although the economic context caused variation in the number of buy-out companies reporting a fall in employment (Wright, Chiplin, Thompson and Robbie, 1990). In a study of 48 large US MBOs completed between 1980-1986, Kaplan (1989) reports a median change in employment following the buy-out for these companies of 0.90 per cent, indicating a slight decrease in employment level. However, employment increased in 50 per cent of the MBO companies, but the growth in employment was 12 per cent less compared to other companies in the same industry. Controlling for post-buy-out divestitures, more than 60 per cent of these companies show a median increase in employment of 4.9 per cent, which is still 6 per cent lower than the industry adjusted change. The results of this study do not support the view that buy-out gains come from laying off a large number of employees.

Another key feature of buy-outs is that they encourage wider employee share ownership, especially as part of privatisation (Bradley and Nejad, 1989; Pendleton, Wilson and Wright, 1998; Robbie and Wright, 1996). Employee buy-outs directly increase employee share ownership, although the overall number of employee buy-outs is small (Wright, Thompson and Robbie, 1989).

Similar reports of wider share ownership following buy-outs emerge from the study of twelve cases by Van Neerven, Bruining and Paauwe (1996) in the Netherlands. In these cases, buy-out companies spread equity ownership through a variety of mechanisms: direct share ownership as part of the buy-out, granting options on shares or distributing shares under profit sharing schemes. Several buy-outs also reduced labour costs with managers 
adjusting the wages of employees to industry norms and pursuing increased labour flexibility by adjusting the numbers employed to meet changes in demand. In a further attempt to enhance employee commitment, the managers in many of these cases reported an increased use of employee involvement policies and enhanced training to develop employee awareness of customer and business requirements.

These entative findings from a small number of previous studies suggest we need to know more about how a change in business ownership influences the type of HR system in an organisation post-buy-out. Changes in HRM practices following buy-outs may be an important method of aligning the management of employees with the strategic choices of the new owners.

\section{Buy-outs: Opportunities for change}

Buy-outs have traditionally been viewed as involving firms in mature sectors with few investment demands and low growth prospects (Jensen 1989). Cost reduction and strategic refocusing are used to mitigate the downside problems of mature firms and to create value following the transfer of ownership. However, buy-outs may also involve the creation of value in less mature sectors through attempts to release the upside potential of firms allowing product development and incremental innovation to take place that was frustrated under the former ownership regime (Wright, Hoskisson, Busenitz and Dial, 2000; Wright, Hoskisson and Busenitz, 2001). Research from the US, UK and Continental Europe shows that buy-outs are often followed by an increase in (new) product development (Bruining 1992; EVCA, 2001; Wright, Thompson and Robbie, 1992; Zahra, 1995).

The mitigation of downside problems and the release of upside potential are two different strategies that management may pursue. Agency theory offers a useful perspective 
for understanding how HRM may develop, although the two scenarios lead to different expectations.

In the traditional buy-out literature (Jensen, 1993; Wright, Hoskisson, and Busenitz, 2001) it tends to be argued that cost-reduction predominates as managers introduce efficiencies and reduce costs post-buy-out. The agency theory perspective underpinning this claim proposes managers are motivated to seek 'efficiencies' because tighter financial monitoring and control limits their discretion and makes them more accountable to investors after the buy-out (Jensen, 1986; Long and Ravenscraft, 1993; Phillips, 1995). In addition, discretionary expenditure by managers is limited following a buy-out as cash flow is used to service interest payments on high leverage (Jensen, 1986). Remuneration arrangements in buy-outs also narrow the corporate governance gap between investors and management, with managers incentivised to maximise investor returns. Buy-outs may therefore reduce employment, display subsequent below industry employment growth (Kaplan, 1989) and decrease expenditure on indirect management activities such as the personnel function (Wright and Coyne, 1985). In particular, there may be an emphasis on those HR practices that are likely to enhance short term productivity and financial performance and a decrease in those HR practices that might affect performance in the long run but whose effects are more uncertain (e.g. training and development, employee involvement). Thus we might expect lower investments in human capital in mature industries with little possibilities for growth. Hence, we suggest the following propositions:

Proposition 1a: If the downside protection view of buy-outs predominates, we expect a low level of high commitment HR policies and practices after buy-out.

Proposition 1b: If the downside protection view of buy-outs predominates, we expect a decrease in investment in high commitment HR policies and practices after buy-out. 
Agency theory may also be applied to situations involving innovation. Innovative activity typically involves high risk, unpredictability and long time horizons (Holmstrom, 1989). In large, integrated diverse organisations, obtaining reliable information on innovative activity may be prohibitively costly. Bureaucratic measures may be adopted to try to ensure acceptable levels of performance but these measures may restrict experimentation and constrain innovative activity (Francis and Smith, 1995). Managers in the pre-buy-out situation may thus face investment restrictions from headquarters, particularly where their firms are peripheral to the main product line of the parent company (Wright, Ho skisson and Busenitz, 2001). These restrictions reduce the freedom to respond to market developments and give rise to opportunities for a buy-out (Bruining, 1992; Wright, Hoskisson and Busenitz, 2001). Limitations on discretion and incentive alignment may be substitutes (Holmstrom and Milgrom, 1989). The loss of efficiency from restricting managerial discretion through tighter control in large integrated diverse organisations may be outweighed by the benefits of providing the right incentives post-buy-out. It is likely to be difficult to provide the necessary equity incentives pre-buy-out for divisional management that directly relate to performance because of the need to maintain similar remuneration structures across the group and because equity typically relates to the group as a whole not to individual divisions. After the buy-out this situation might be reversed. Instead of obeying orders from headquarters that block innovation and investment in order to optimise the goals of the diversified parent company, the buy-out creates discretionary power for the new management team to decide what is best for the business, how to organise and lead the company, and how to set up a business plan that is most profitable for themselves and the firm (Wright, Hoskisson and Busenitz, 2001). Together with a more moderately leveraged financing structure, in these circumstances we expect changes in firm behaviour as the new 
owners have greater decision-making autonomy. Consistent with this argument, studies have shown the greater importance of increases in managerial equity ownership, as opposed to greater leverage, in enhancing the performance of firms that have been bought out (Phan and Hill, 1995; Thompson, Wright and Robbie, 1992).

The shift from maintaining the status quo pre-buy-out to acting more efficiently and entrepreneurially post-buy-out may require the development of HRM to achieve the required levels of organisational flexibility. Management may need to develop employees' awareness and competency in relation to customer and business requirements and to increase their commitment. This may necessitate making employees more market oriented through HR practices involving greater training and employee involvement in decision making in order to take advantage of the skills and information possessed by employees. There may also be a need to incentivise employees through share ownership to encourage this shift in behaviour. Hence:

Proposition 2a: If the release of upside potential view of buy-outs predominates, we expect a high level of investment in high commitment HR policies and practices.

Proposition 2b: If the release of upside potential view of buy-outs predominates, we expect an increase in investment in high commitment HR policies and practices.

The high commitment HR policies we might expect and measure in this research arise from prior research on high involvement work practices (HIWP's) and high performance work practices (HPWP's). This is a specific area of research within the HRM and performance debate that bcuses on the HR practices that increase employee commitment (e.g. Appelbaum, Bailey, Berg and Kalleberg, 2000). For example, Arthur (1994) defines commitment HR systems in terms of decentralisation, employee participation, general 
training, skill development, social events, due processes, employee benefits, and high wages. Kalleberg and Moody (1994) argue that high performance work systems reflect decentralisation, job training, compensation (performance related pay) and firm internal labour markets. Ichniowski, Shaw and Prennushi (1997) define high involvement practices in terms of incentive pay, selective recruitment and selection, teamwork, employment security, flexible job assignments, skills training, communication, and good labour relations. Bae and Lawler's (2000) high involvement HR strategies consist of extensive training, empowerment, highly selective training, performance-based pay, and broad job design. Therefore we can conclude that decentralisation, employee participation, employee development of skills and knowledge, selective recruitment and selection, performance related pay (in particular group based pay), communication and information sharing, and internal promotion opportunities are the building blocks of high commitment HR policies and practices (see also Batt, 2002; Guthrie, 2001Ramsay, Scholarios and Harley, 2000).

In the following section we highlight the different institutional contexts for HRM in the UK and the Netherlands where we conducted our research that may further help to explain differences in post-buy-out HRM in the two countries.

\section{Institutional contexts for buy-outs in the UK and the Netherlands.}

Institutional rules on employment, pay and participation set standards with which management needs to comply, thus reducing the range of discretionary HRM policies available to management (Oliver, 1997). Regulatory pressures differ between Anglo-Saxon and Germanic type environments (Boselie, Paauwe and Jansen, 2001; Gospel and Pendleton, 2003; La Porta, Lopez-De-Silanes, Shleifer and Vishny, 1997) suggesting HRM will not necessarily take the same path in the Anglo-Saxon context of the UK versus the Germanic or Rhineland context of the Netherlands. 
Paauwe and Boselie (2003) apply institutional theory (e.g. DiMaggio and Powell, 1983) to explain differences in HR decision-making processes depending on differences in organisational contexts. In general, institutional theory shows how the behavior of organisations is a response not solely to market pressures but also to formal and informal institutional pressures, regulatory pressures, general social expectations and the actions of leading organisations (Greenwood and Hinings, 1996).

Gospel and Pendleton (2003) make a distinction between the USA and the UK on the one hand and Germany and Japan on the other, based on the idea of fundamental differences in capitalism. The authors argue that the Anglo-American model appears to enhance managerial choice in contrast to the German model and the Japanese model, which both can be characterized by significant regulation or coordination at the macro level. The Dutch model is much closer to the co-ordinated market economy of Germany than to the liberal market economies of the UK and the US, again suggesting significant differences between the UK and the Netherlands. The varieties of capitalism approach focuses on the role of institutions in capital and labor markets and, of particular relevance here, the levels of commitment of shareholders and employees to the firm (Hall and Gingerich, 2001). Hence, in the Netherlands, a more stakeholder-oriented approach traditionally emphasizes the high commitment of employees, while in the UK a more shareholder oriented approach emphasizes low employee commitment. Industrial relations in the Netherlands are characterized by a high degree of institutionalization in terms of (a) significant trade union influence, for example through collective bargaining agreements (CBAs), (b) strong labor legislation, for example covering employment security, safety, illness, and contingent work, and (c) the legal status of Works Councils in organisations with more than 50 employees.

The United Kingdom is less institutionalized than the Dutch system of industrial relations (Visser and Hemerijck, 1997) with contracting collective bargaining, declining 
trade union influence, an emphasis on flexible labor markets and works council legislation only covering European Works Councils (Edwards, Hall, Hyman, Marginson, Sisson, Waddington and Winchester, 1998).

Visser (2003) provides more detailed information on two specific indicators that can be used to measure institutionalization: the degree of unionization and the coverage of collective bargaining agreements (CBA). The degree of unionization is slightly lower in the Netherlands (about 25 per cent in 1997) than in the United Kingdom (about 30 per cent in 1997), but there is a major difference with respect to the CBA coverage in the Netherlands (over 80 per cent of all employees in 1998) compared to the UK (about 30 per cent of all employees in 1998). The latter results reflect the powerful position of Dutch trade unions in the collective bargaining process in spite of the relatively low degree of unionization. Hence:

Proposition 3a: Buy-outs in the Netherlands are significantly more likely than buy-outs in the UK to invest in high commitment HR policies and practices.

According to DiMaggio and Powell (1983), organisations in a population facing the same set of environmental conditions will come to resemble each other. DiMaggio and Powell (1983) emphasize the concept of institutional isomorphism for understanding similarities between organisations. Three institutional mechanisms drive institutional isomorphism: coercive mechanisms, normative mechanisms and mimetic mechanisms.

Institutional theory suggests that coercive differences at the national level, which arise from the influences such as labor legislation and trade unions, are reflected in the degree of institutional isomorphism at the organisation level. Extensive legislation and directives at the national level lead to high degrees of HR homogeneity at the firm level. The United 
Kingdom is less institutionalized in terms of coercive mechanisms than the Netherlands (Edwards, Hall, Hyman, Marginson, Sisson, Waddington and Winchester, 1998; Visser and Hemerijck, 1997; Visser, 1998).

Boselie, Paauwe and Richardson (2003) found that labor regulations encourage homogeneity in the HR of Dutch organisations as corporatism has withstood the pressures of international competition (Visser, 1998). Based on the likely impact of institutional environments, we expect differences between the highly institutionalized Dutch system and the less institutionalized UK system of industrial relations with respect to the management of employee relations following buy-outs. New institutionalism suggests that the management of employee relationships (e.g. HR practices and policies) is more homogeneous among firms in the Netherlands than firms in the UK.

Proposition 3b: Employee relations, in particular $H R$ practices and policies, are more homogeneous in buy-outs in the Netherlands than in buy-outs in the UK.

Further, notwithstanding the agency theory perspective, high degrees of institutionalization are expected to lead to restrictions with respect to the discretion to change HR practices and policies. Firms in the Netherlands are more likely to be 'trapped' in a highly institutionalized web of regulations than firms in the UK and therefore are less likely to change their HRM after fundamental organisational changes, such as a transfer of ownership.

Proposition 3c: The changes in HR policies and practices after a buy-out are expected to be bigger in the less institutionalized context of the UK than in the highly institutionalized context of the Netherlands. 
These arguments can also be extended to the role of trade unions, both in terms of their recognition for collective bargaining purposes and also in respect of management's attitudes towards union membership. As noted above, Dutch legislation has institutionalized collective bargaining agreements. In contrast, in the UK collective bargaining is contracting. Thus at an individual firm level, it is expected that there will be greater recognition of unions for collective bargaining both before and after buy-out. Similarly, there may be institutionalized differences in the attraction of management towards union membership. Hence:

Proposition 3d: The recognition of trade unions for collective bargaining purposes before, immediately after and subsequent to buy-out is expected to be greater in the highly institutionalized context of the Netherlands than in the less institutionalized context of the $U K$.

Proposition 3e: Management's attitude towards union membership is expected to be more positive in the highly institutionalized context of the Netherlands than in the less institutionalized context of the UK.

\section{Data collection and sample}

A questionnaire with a common core of questions was developed on the basis of prior literature and discussions with practitioners. The survey instrument was piloted amongst academics, financiers, advisers and buy-out management. The questionnaires, in English and Dutch, respectively, were mailed to the general director/owner of the firm, since these directors were assumed to have direct esponsibility for their personnel and thus reliable knowledge of employee relations in their firms. The survey was conducted in 1999-2001. 
All UK buy-outs completed in the period 1994-1997 and all Dutch buy-outs completed between 1992 and 1998 were surveyed. The overall usable response rate was 18.1 per cent. After reminders and telephone calls we received usable responses from 145 buy-outs in the UK (18.1 per cent) and 45 buy-outs in the Netherlands (18.2 per cent). All the buy-outs in the sample had a transaction value above $€ 7.5 \mathrm{~m}$ and were supplied by the Centre for Management Buy-Out Research at Nottingham University (CMBOR). CMBOR has collected data on buy-outs since the late 1970s and currently has records of over 16,000 buyouts in the UK and Continental Europe, effectively the population of buy-outs. The minimum size cut-off was taken on the basis that enterprises above this size are likely to employ a significant number of employees and thereby have more formal human resource management procedures to deal with the complex task of management (Sisson and Marginson, 1995). Comparisons of the distribution of the responses with the CMBOR database for each country showed that the sample was generally representative for the population of buy-outs in terms of size, source of transaction and industry. With respect to industry categories and transaction values chi-squared tests for differences between the sample and population were insignificant in the UK. In the Dutch sample the category of business services is slightly over-represented compared to the population. A chi-squared test suggested no significant difference between the sample and population shares.

In our survey we asked respondents to indicate the presence or absence of a range of high commitment management practices in the buy-out with questions sourced from several previous studies (Cully, Woodland, O’Reilly and Dix, 1999; Guest and Hoque, 1994; Wood and Albanese, 1995). High Commitment Practices or High Performance Work Practices are those practices that are presumed to lead to high employee commitment (employee 'devotion'), increased employee flexibility, decreased employee turnover and high 
productivity standards (e.g. Appelbaum, Bailey, Berg and Kalleberg, 2000; Batt, 2002; Guthrie, 2001; Ramsay, Scholarios and Harley, 2000).

We also asked whether a wide range of personnel practices had changed compared to before the buy-out. We used a 5-point Likert-type scale ranging from 'decreased a lot' to 'increased a lot' with respect to total number of employees, HR management issues, for example, the amount of training employees receive, and payment and rewards. Employment was measured in terms of whether the total number of employees had 'increased', 'decreased' or 'remained the same' after the MBO. We asked respondents whether real earnings 'increased', 'decreased' or 'stayed the same' as a result of the buy-out for the directors of the $\mathrm{MBO}$, middle managers, line managers and non-managerial employees. Industrial relations are measured by comparing the recognition of trade unions for collective bargaining, the willingness of directors/owners to negotiate with union representatives; and management attitude towards union membership among employees (see Tables 3 and 4). Ttests were carried out in order to determine whether or not significant country differences exist.

\section{Results}

First, we present the descriptive findings of the comparison between the UK and Dutch buyouts with respect to the presence of high commitment management practices. Second, we report changes in employee relations, in particular total employment, HR practices and payment. Third, we focus on changes in industrial relations in the UK and the Netherlands. Fourth, we provide more detailed insights into the changes following buy-outs in two cases from the contrasting institutional contexts of the UK and the Netherlands. 
Of twenty high commitment practices measured, ten are reported to be used by over half of the buy-outs in both the UK and the Netherlands (Table 1). For example, with respect to employee involvement methods, a majority of the employees in buy-outs in both countries receive information on company performance and nearly half of them are involved in setting performance targets. If we compare the reported high commitment policies of both samples, a substantial proportion of the employees in both UK and Dutch buy-outs work in formally designated teams and are trained to do jobs other than their own. Other high commitment management practices applicable in almost half of buy-outs in both countries are the way team members decide how work is done and the use of internal promotion. These findings provide support for Proposition 2a rather than Proposition 1a.

However, there are also some differences in the reported HR policies between the countries. Dutch buy-outs were more likely than UK buy-outs to report the use of thirteen of these practices, while UK buy-outs reported greater use of seven policies. Dutch buy-outs were statistically more likely to report the use of performance appraisal, profit-related pay, newsletters/staff bulletins, team briefings, problem solving groups, a guaranteed job security or no redundancy policy, a majority of employees having a minimum five days training per year and employees deciding how their work is done. Buy-outs in the UK reported a statistically significant greater use of merit pay and suggestion schemes. Overall, Dutch buyouts were therefore more likely to report high commitment management policies. These findings provide support for Proposition 3a.

- insert Table 1 about here - 
Overall, the results in Table 2 suggest that employee relations improve as a direct result of the buy-out. Managers reported increases in the total number of employees, the importance of HRM issues, resources devoted to managing employees, the amount of training employees receive, the flexibility shown by employees, workers' responsibility for their jobs, and the level of trust between managers and workers. Other issues did not change dramatically but stayed about the same including: avoiding lay-offs, the use of internal promotion, the use of temporary workers, the similarity of terms and conditions between managers and nonmanagers, and the percentage of non-managerial employees owning shares in the company. The results suggest that buy-outs create leeway for the new owners to change employee relations, in particular with respect to growth in terms of number of employees, employee participation, employees' trust and earnings. These findings provide support for Proposition $2 b$ rather than Proposition $1 b$.

- insert Table 2 about here -

\section{Change in employee relations in Dutch and UK buy-outs}

To examine whether HR practices and policies are more homogeneous in the highly institutionalised context of the Netherlands compared to the UK we test for the equality of variances for each HR item. We find that UK buy-outs are significantly different than the Dutch buy-outs on practically all the HR-issues (Table 2, last column). The UK buy-outs show substantially larger variances than the Dutch cases, indicating larger variation in the pattern of change in employee relations in the UK compared to the more homogeneous scores of the Dutch firms. Proposition $3 b$ is thus supported.

The next step in our analysis focuses on significant differences in the impact of a buyout on employee relations in the UK and the Netherlands. We find significant differences in 
the changes in employee relations in buy-outs in the UK and the Netherlands (see t-tests in Table 2). Using t-tests we compared the mean scores of issues between the institutionalised Netherlands and the less institutionalised UK. Although both groups of buy-outs show improvements, statistically fewer improvements in HRM were reported in the Netherlands compared to the UK on six items: 'importance of HRM issues'; 'the amount of training employees receive'; 'the flexibility shown by employees'; 'workers responsibility for their jobs'; 'the total number of employees working in teams'; 'use of temporary workers only to cover shortages'; and 'the number of staff receiving merit pay'. Proposition $3 c$ is thus supported.

These findings imply that the UK has risen up towards although still not matching Dutch standards of HRM. The majority of these 'best practices' appear to be institutionalized in the Netherlands prior to the buy-out through labour legislation (e.g. collective health care insurance and pension schemes) or collective bargaining agreements (e.g. wages, employee benefits, training and development). The amount of training employees have to receive is often part of a collective bargaining agreement in the Netherlands represented by a minimum percentage of total wages. Flexibility in terms of contingent work is strictly tied to bbour legislation in the Dutch Flexwet, a law on employment security of contingent workers in the Netherlands. As a result of the opposition of Dutch trade unions to individual performance related payment systems, merit pay for staff is not as widely used as in the UK. Thus, there seems to be logic for the difference between the UK and the Netherlands with respect to the impact of a buy-out on employee relations. What buy-outs in both countries seem to share equally are increases in the total number of employees, their unchanged behaviour with respect to avoiding lay-offs, and the slight increase in the percentage of non-managerial employees owning shares in the firm. 
With respect to payment and rewards, Table 2 shows that both groups report an increase in earnings for all worker categories (3-point scale) as compared to before the buy-out. However, the Dutch buy-out directors score more moderately than the UK buy-out directors. Increases in pay for UK buy-out directors are significantly higher than their Dutch colleagues (at a 90 per cent confidence interval), while there were no differences in changes in the pay of non-managerial employees between both samples.

\section{Industrial relations in $U K$ and Dutch buy-outs}

Buy-outs in the UK and the Netherlands operated in different industrial relations contexts. The recognition of trade unions for collective bargaining before the buy-out, immediately after the buy-out, and subsequently is significantly higher in the Netherlands than in the UK (Table 3). Subsequent to the buy-out, 60 per cent of the Dutch buy-outs at the time of the survey recognized trade unions for collective bargaining, in contrast to 34 per cent of the UK buy-outs. Apparently UK and Dutch buy-out managers do not share a common framework for collective bargaining.

- insert Table 3 about here -

The differences in union recognition reflected the general attitude of managers towards trade union membership among employees at the establishment (see Table 4). In the Dutch buy-outs, a majority ( 88 per cent) of directors expressed a neutral attitude towards trade union membership among their employees. This is indicative of the impact of regulations encouraging a strong sharing of common values among Dutch managers towards the effects of trade unions on employee relations. Only 50 per cent of the UK buy-outs were neutral towards trade union membership, and in 40 per cent of the UK buy-outs managers were not 
in favour of membership at all. The negative attitudes of managers to trade union membership in the UK buy-outs differ fundamentally from their Dutch counterparts.

-insert Table 4 about here-

The majority of Dutch buy-outs in this sample have a works council: 29 firms or 64 per cent of the Dutch buy-outs had one installed before the buy-out and 30 firms had one afterwards. In contrast, none of the UK firms reported a works council. Thus, the results with respect to trade union recognition for collective bargaining, general attitude of managers towards trade union membership, and works councils installed, demonstrate significant differences between the UK and the Dutch institutional environment and provide support for Propositions $3 \mathrm{~d}$ and $3 \mathrm{e}$. These empirical findings indicate institutional industrial relations mechanisms continued in buy-outs in the Netherlands and UK buy-outs faced fewer institutional constraints.

\section{Case study evidence}

Drawing on two case studies of buy-outs in the UK and the Netherlands we will now illustrate in more detail the effects of the institutional differences between the two countries. Data were gathered from interviews with the parties involved in the buy-outs as well as from secondary published information.

\section{Unipart: A UK Buy-out}

The automotive parts producer and distributor Unipart was formerly owned by the Rover Group. In 1987, Unipart was privatised in a management-employee buy-out. Seventy managers obtained 10 per cent of the equity and the general body of employees held 12 per 
cent. Seventy per cent of employees took up the initial offer to buy shares. Private equity firms held 56.3 per cent of the equity with the balance being retained by the Rover Group. The private equity firms selected took a long term perspective of their investment.

Prior to the buy-out, HRM in Unipart was influenced by the problems of the troubled parent. Industrial relations had been poor in the group for many years and the need to deal with trading difficulties had led to a focus on rationalisation of the workforce and restrictions on investment. In 1985, the period leading up to privatisation, employment in Unipart was reduced by 15 per cent.

The management of Unipart explicitly took the approach after the buy-out not to focus on short-term shareholder value (Jackson, 1997). Rather than management taking a large majority of the equity and growing profits over a two to three year period through further rationalisation before floating the company, the decision was taken to spread ownership and invest heavily in a new delivery system and to develop long term trading relationships. This strategy involved a more flexible and developmental approach to HRM.

Following the buy-out, foremen and supervisor positions were replaced by team leaders as the company adopted Japanese approaches to operations. Instead of being based around function, machines were grouped into cells in which small, flexible teams of employees would carry out a variety of tasks. The factory's team of workers have devised new, faster ways of setting up machines to give more flexibility in the production process. The company also developed 'contribution circles' initiated by management and employees that worked on a large number of projects with resultant significant reductions in costs. Seven layers of management between the factory's general manager and the shop floor were cut to three. In early 1992 , the company ended trade union recognition on the grounds that the unions were undermining the company's strategy to develop multi-skilling, team briefings, quality circles and direct communication between management and employees. 
An important change in employees' remuneration was also introduced. All 4,500 employees are assessed on their individual performance annually, with those with higher ratings being eligible for a higher proportion of share options. An employee's performance is assessed as satisfactory, good or excellent. Those assessed as satisfactory are eligible for one share option for each ordinary share purchased, up to two share options for each ordinary share purchased in respect of those assessed as excellent. The company also changed the structure of remuneration so that all workers were paid salaries rather than hourly wages. Recognising the importance of maintaining the incentive of employee ownership, a share buy-back scheme was introduced in 1988 with the aim of creating a pool of shares that could be distributed to new employees.

In 1993, the company created Unipart University with the aim of enhancing the skills of employees based on the Japanese model of managers sharing knowledge with employees but at the same time managers also learning from employees. The CEO of Unipart clearly expressed a key aspect of HRM following the buy-out:

"We realised that if we were to compete and survive internationally, we had to make a commitment to making our people more skilled...The constant search for improvement is now a way of life in Unipart”.

By 1994, 90 per cent of employees had undertaken courses at the university. The university plays a key role in retraining workers displaced by cost cutting. This has meant that employees can be retained rather than being made redundant. In the decade following the buy-out there were no forced redundancies, with there being a guarantee of employment continuation for those whose jobs disappear through restructuring. 
Boekhoven-Bosch: A Dutch Buy-out

The printing company Boekhoven-Bosch was formerly owned by the publishing company Elsevier. In 1987, Boekhoven-Bosch was divested in a management buy-out to its managers backed by two private equity firms. The general manager and the Employee Consortium each owned 5 per cent of the equity, private equity firms owned 58.4 per cent and 31.6 per cent of the shares remained initially with the parent. The private equity funders are known as long-term investors. At the time of the buy-out the workforce comprised 450 employees.

Prior to the buy-out, HRM in Elsevier was prescribed by a headquarters based department, responsible for coordinating the personnel arrangements, such as labor conditions across all subsidiaries of Elsevier. The HRM-department in Boekhoven-Bosch changed after the MBO from a regulating and bureaucratic body to a department with a more central role in the implementation of the HRM policy of the firm (Van Neerven, Bruining and Paauwe, 1996).

In February 1987, and following the withdrawal from purchase negotiations by the US based printer Donnelley \& Sons, the works council invited the CEO Mr. Van Ek to relaunch his buy-out plans for the firm. According to the Law on Works Councils, the works council of Boekhoven-Bosch set up a committee to examine the desirability and feasibility of the proposed MBO. The trade union "Druk en Papier", a union for the printing industry belonging to the largest Dutch trade union FNV, organized meetings with the works council that focused on issues relating to numbers employed, guarantee of job content and job level, and continuation of the collective bargaining agreement of the printing industry. The works council proposed that the employees should participate in the buy-out as compensation for the loss of the former corporate benefits such as free subscription to two daily newspapers, discounts on books published by Elsevier and three yearly tax free gifts of 100 Dutch Guilders (round 45 euro or £30). A foundation named "Employees hterests Boekhoven- 
Bosch" was established to implement the worker's participation plan by using part of the individual saving from the salaries for the acquisition of shares by the employees. After six weeks the council supported the buy-out and advised management to proceed. The trade unions were particularly in favour of the MBO because of the experience and recognized skill of the director of the firm who was to lead the buy-out.

In 1988 and 1989 the management invested in robots and computers to take advantage of the trend towards desktop publishing and electronic printing and to increase the volume of production to reduce costs. Subsequently, management stimulated strong cooperation between the HRM and the quality department in order to integrate the new job requirements and work attitudes of the operating employees with the new quality requirements for meeting printing orders. Post-MBO, employees became process operators, with more autonomy and responsibility for taking the initiative to control operational processes, contact customers, and ensuring the quality of products without waiting for orders from their bosses. Accordingly, responsibilities were decentralized. To improve internal communication, team meetings were introduced in each section. Anything that related to the job was open for discussion in both formal and informal meetings (Van Neerven, Bruining and Paauwe, 1996).

In 1990 Boekhoven-Bosch introduced job profiles that described the characteristics and responsibilities of hundreds of jobs, as well as informative and appraisal interviews, linked to a system of career guidance. An annual system of job performance evaluation was started. The resulting individual career development, job rotation and management development were largely neglected prior to the buy-out. This post-MBO change in HRM led to an increase in training for both employees and middle management in order to develop a multi-skilled and flexible workforce. More hours training were devoted to communicating and work briefing skills. During this period of transition, people from the HRM department 
and the works council joined forces to control the loss of days caused by sickness. No employees were laid-off, but staff vacancies were not filled. With respect to the changes, the CEO of Boekhoven-Bosch clearly expressed the constructive attitude of the firm's works council:

\footnotetext{
"The works council is a responsible body with an advisory influence on HRM that without doubt has increased post-MBO. I take them seriously but I also demand that they focus on the key issue of the firm's business".
}

In place of the previous Elsevier terms, a number of new employment terms were introduced, including: profit sharing, the opportunity to share certificates through a seven year share saving scheme, a five times per year bonus payment of 100 Dutch Guilders to each employees and a free daily newspaper per employee.

Comparing the two case studies we can see that in the Dutch case the works council plays an active role in the relaunch of the MBO plans of the CEO, and in accordance with the law on works council (articles 24, 25 and 27) a constructive role in the subsequent stages of gathering information (e.g. employment and business plan), of advising (e.g. reorganisation and change in management) and approving (e.g. pay, pension, profit sharing and job classification) HR issues during the buy-out. Representatives of the trade unions were invited as counselling specialists to inform and advise the members of the works council. These institutions both retrain management choice and enable efficient investments in skills and the further development of employee commitment. In contrast, managers in the UK buy-out had greater leeway and chose to implement new HRM practices to develop employee commitment with little recourse to the trade unions. Despite these differences in 
communication between management and employees in the two MBOs, the cases also have much in common. For example, both pursued upside strategies with changes in strategy and organisation involving increased training in quality and customer service for employees, and resulting changes in job content and other HR policies. These case studies support the findings of the survey data that buyouts do not generally improve performance through an attack on the terms and conditions of employees.

\section{Conclusions}

The findings reveal buy-outs have a positive effect on employee relations in both the UK and the Netherlands. The high level of investment in high commitment HR policies and practices and the increase in these investments following a buy-out, suggest that buy-outs release their upside potential rather than protect the downside of their operations. Differences in institutional setting between the UK and the Netherlands appear to moderate the effect of buy-outs on employee relations. For example Dutch managers in contrast to UK managers recognise trade unions for collective bargaining purposes and have neutral attitudes towards union membership, leading to more investment in high commitment HR practices and policies but also to more homogeneous employee relations in the buy-out firms than in the UK. However, the effect of buy-outs on employee relations is smaller in the highly regulated Dutch context than in the less regulated UK context for six out of eleven HR management issues. The stronger scores on changes in employee relations in UK buy-outs imply that the UK buy-outs raised their standard of HR practice closer although still slightly below the Dutch level. The effect of buy-outs is also positive on the real earnings of directors, middle managers, line managers and non-managerial employees. Although the

change does not quite reach statistical significance, the UK buy-out directors and line managers report more frequent increases in earnings than the Dutch. 
These findings raise three main questions. First, why do buy-outs affect employee relations positively? Second, why do UK buy-outs have a greater influence on employee relations than on Dutch buy-outs? Third, why do employees on the whole appear to bene fit from buy-outs?

Referring to our first question, the change of ownership involved in buy-outs may have several positive effects. First, new ownership releases the buy-out from former company policies and creates the opportunity to reappraise policies. The leeway after the buy-out can be used to expand the number of employees and to invest in employee development. Second, the incentives for investment may have changed. Compared to the business divisions of larger organisations, buy-outs may be more able to invest for the longer term rather than provide cash for the business group. The pay-off from long-term investments may be higher as it may be captured by the buy-out rather than returned to head office. In short, it may be easier to re-invest profits in buy-outs to grow the business. This may involve human capital investments. Third, buy-outs may embark upon a new business strategy that requires a change of HR policies. For example, a new focus on quality service in a niche market may require significant investments in staff training and development. Fourth, the uncertainty created by the change in ownership may necessitate positive HR investments to build employee trust and commitment to the new owners. The application of HR policies and practices, for example, training and development, payment, increasing workers responsibility, might be a powerful tool for management to gain trust and commitment. The implementation of new HR practices may also be intended as a signal from managers to employees of the sustainability of the organisation. Fifth, the introduction of new managers may simply inject new thinking about the value of investing in HRM. All of these appear feasible explanations and future research could explore which is the main mechanism for 
upgrading HRM in buy-outs. The evidence of both case studies supports these positive effects of change of ownership on HR investment.

The impact of institutional context provides insights into the second question of why UK buy-outs have a more positive influence on employee relations than Dutch buy-outs? As firms are captive in an institutional environment (Tolbert and Zucker, 1983) they gain a "common understanding of what is appropriate and fundamentally meaningful behaviour" (Zucker, 1983). The recognition of trade unions for collective bargaining, the attitude of managers towards trade union membership and the Works Council system all prevent Dutch buy-outs from embarking upon radical changes in employment practices post-buy-out. Our empirical findings on industrial relations confirmed that buy-out firms in the Netherlands face a more institutionalised environment than buy-out firms in the UK. In the Netherlands collective bargaining agreements (CBAs) have been institutionalised by legislation with a widely accepted role for trade unions since 1927. Another typical example of the institutionalised Dutch setting is the obligation for organisations with more than 50 employees to install a works council (Works Councils Law, Article 2). These institutional mechanisms, embedded in the industrial relations system, appear to be responsible for fundamental differences between the UK and the Netherlands in the magnitude of change in employee relations after the buy-out. The differences are represented by a high versus low degree of institutionalisation in industrial relations, and moderate the relationship between buy-outs and employee relations. As a result, the positive effect of the buy-out on the employment relationship is smaller in the Dutch context than in the UK context. Six out of eleven HR management issues increased more in the UK cases than in the Dutch cases. This suggests that Dutch buy-outs have either less leeway to change the existing HR practice because of legal restrictions or the specific HR practice is already fixed through collective bargaining agreements. Dutch buy-out managers are also pressured into conformity by 
regulatory structures based on legislation and public expectations (Oliver, 1991). These pressures are less in the UK where buy-out directors appear to have greater freedom to reassess employee relations. Their actions do not appear to be driven nor evaluated by the same institutional normative influences (Davis and Greve, 1997) as in the Netherlands. Therefore they can decide on policies informally and in a non-committed way, in contrast to Dutch buy-out managers who must comply with the minimum standard for employee relations pre-buy-out, which are on a higher level than for their UK counterparts. This explains the relatively stronger effect of buy-outs on the employee relationship in the UK that contributes to narrowing the gap in the level of HR practices between the two countries.

The third question raised by our findings is why do real earnings increase for all employee categories after buy-out? We believe that earnings are seen as an important means of motivating people for the risk to run a company themselves. The financiers of buy-outs incentivise managers by rewards triggered only when certain turnover and/or profit targets of the buy-out are met. Buy-out managers are also likely to incentivise all their staff to meet these targets and thereby share some of the gains of improved performance. It is also interesting to note that UK buy-out managers more frequently report an increase in pay for directors and line managers than their Dutch counterparts. Although we can only speculate on the causes we can think of two explanations. First, it may reflect market norms and expectations from financiers about appropriate and acceptable trade-offs between risks and pay after a buy-out. The risk may be similar in the two countries but UK entrepreneurs may simply expect larger rewards. Second, the industrial relations structure in the Netherlands may redistribute a share of profits from senior managers to all staff in buy-outs, whereas in the UK managers may take a larger share of rewards. Buy-outs in the Netherlands may follow the Dutch system of 'concertation with consensus' and 'jobs before income' (Visser, 1998: 284) restricting pay rises for managers. 
Finally, what lessons can be learned from these findings for future research on the effects of buy-outs on employee relations?

First, we need to study the motives of buy-out teams for developing new HR policies after the buy-out more thoroughly. Longitudinal research in this area on HR investment before, immediately after, and 1 to 2 years after the buy-out could explore whether the HR investment is temporary and merely a management tool for signalling the new owners' best intentions, or represents a new and relatively enduring management philosophy of investing in employees.

Second, it may be fruitful to distinguish between different types of buy-outs. In certain buy-outs employees also take an equity share alongside management and we would expect this to deter a cost cutting approach towards employment. In other buy-outs, external managers 'buy-in' introducing new ideas and approaches. 'Buy-ins' are certainly likely to lead to a change of HRM policies although we do not know currently whether the effect is to enhance or downgrade HRM overall. It would also be useful to identify the factors that encourage new managers to upgrade HRM.

Third, for a better understanding of the increased leeway after the buy-out we need to examine the role of investors such as venture capitalists and banks. In particular, it would be useful to explore financier involvement and the effect of the financial incentives and targets set for buy-outs. For example, it may be possible to distinguish between different types of financiers of buy-outs. Some financiers may manage only by setting challenging performance targets and seek a quick return from their investment. As a consequence buyout managers may still face financial restrictions and be deterred from long-term investments in human assets. In contrast, other financiers may take an active involvement in building the business over a longer term and thereby encourage employee development. 
Fourth, it would be helpful to explore changes in the business strategies of buy-outs and the implications for HRM. Whereas buy-outs engaged in a 'buy and build' strategy may develop markets and staff, other buy-outs may retrench into cost competition and squeeze labour costs, others may do both.

Finally, the significant differences in employee relations between the UK and Dutch buy-outs teach us to be very cautious with international comparable research in this area. Labour market institutions shape employee relations in organisations as well as the impact of buy-outs. Future work assessing the impact on HRM of changes in corporate governance must account for the effects of national institutional contexts. 


\section{References}

Appelbaum, E., Bailey, T., Berg, P. and Kalleberg, A.L. (2000) Manufacturing advantage: why high-performance work systems pay off. Ithaca/London: Economic policy Institute \& ILR Press.

Arthur, J.B. (1994) 'Effects of human resource systems on manufacturing performance and turnover', Academy of Management Journal, 3(37): 670-87.

Bae, J. and Lawler, J.J. (2000) 'Organisational performance and HRM in Korea: impact on firm performance in an emerging economy', Academy of Management Journal, 43: 502-17.

Batt, R. (2002) 'Managing customer services: Human resource practices, quit rates, and sales growth', Academy of Management Journal, 3(45): 587-97.

Boselie, P., Paauwe, J., and Jansen, P.G.W. (2001) 'Human Resource Management and Performance: Lessons from the Netherlands', The International Journal of Human Resource Management, 7(12): 1107-25.

Boselie, P., Paauwe, J., and Richardson, R. (2003) 'Human Resource Management, Institutionalization and Organisational Performance: A Comparison of Hospitals, Hotels and Local Government', The International Journal of Human Resource Management, 8(14): 1407-29.

Bradley, K., and Najed, A. (1989) Managing Owners: The National Freight Consortium in Perspective. Cambridge: Cambridge University Press.

Bruining, J. (1992) Performance Improvement after Management Buy-Out. Unpublished $\mathrm{PhD}$ Erasmus University Rotterdam.

CMBOR (2002) 'Recent Trends in UK Buy-outs and Buy-ins', In: Wright, M. and Burrows, A. (eds) Management Buy-outs. Nottingham: Centre for Management Buy-out Research, autumn: 9-36.

CMBOR (2003) 'Market Overview' and 'The Netherlands', In: Wright, M., Burrows, A. and Scholes, A. (eds) European Management Buy-outs. Nottingham: Centre for Management Buy-out Research.

CMBOR/Initiative Europe (1991) Europe Buy-out Review 1990. London: Initiative Europe.

Cully, M., Woodland, S., O'Reilly, A., and Dix, G. (1999) Britain at Work. London: Routledge. 
Davis, G.F., and Greve, H. (1997) 'Corporate Elite Networks and Governance Changes in the 1980's', American Journal of Sociology, 1(103): 1-37.

DiMaggio, P.J. and Powell, W.W. (1983) 'The iron cage revisited: institutional isomorphism and collective rationality in organisational fields', American Sociological Review, 48: 147-160.

Edwards, P., Hall, M., Hyman, R., Marginson, P., Sisson, K., Waddington, J., and Winchester, D. (1998) 'Great Britain: From Partial Collectivism to Neo-liberalism to Where?' In: Ferner, A. and Hyman, R. (eds), Changing Industrial Relations in Europe. Oxford: Blackwell: 1-54.

European Private Equity and Venture Capital Association (EVCA) (2001) Survey of the Economic and Social Impact of Management Buy-outs and Buy-ins in Europe. Research paper, Zaventum, Belgium.

Francis, J. and Smith, A. (1995) 'Agency costs and innovation: some empirical evidence', Journal of Accounting and Economics, 19: 383-409.

Gospel, H. and Pendleton, A. (2003) 'Finance, corporate governance and the management of labour: A conceptual and comparative analysis', British Journal of Industrial Relations, 3(41): 557-82.

Greenwood, R. and Hinings, C.R. (1996) 'Understanding radical organisational change: bringing together the old and the new institutionalism', Academy of Management Review, 4(21): 1022-55.

Guest, D. and Hoque, K. (1994) 'The Good, the Bad and the Ugly: Employment Relations in New Non-union Workplaces', Human Resource Management Journal, 5: 1-14.

Guthrie, J.P. (2001) 'High-involvement work practices, turnover, and productivity: Evidence from New Zealand', Academy of Management Journal, 44: 180-90.

Hall, P. and Gingerich, D. (2001) Varieties of capitalism and institutional complementarities in the macroeconomy: an empirical analysis. Paper presented at the American Political Science Association Conference, San Fransisco.

Holmstrom, B. (1989) 'Agency costs and innovation', Journal of Economic Behavior and Organisation, 12: 305-27.

Holmstrom, B. and Milgrom, P. (1990) 'Regulating trade among agents', Journal of Institutional and Theoretical Economics, 146: 85-105.

Ichniowski, C., Shaw, K. and Prennushi, G. (1997) 'The effects of human resource management practices on productivity: a study of steel finishing lines', American Economic Review, 87: 291-313. 
Jackson, T. (1997). The lean paternalist. Financial Times, February: 14.

Jensen, M.C. (1986) 'Agency costs of free cash flow, corporate finance and takeovers', American Economic Review, 76: 323-29.

Jensen, M.C. (1989) 'Eclipse of the Public Corporation', Harvard Business Review, 67: 6174.

Jensen, M.C. (1993) The Modern Industrial Revolution, Exit and the Failure of Internal Control Systems', Journal of Finance, 48: 831-80.

Kalleberg, A.L. and Moody, J.W. (1994) 'Human resource management and organisational performance', American Behavioral Scientist, 37: 948-62.

Kaplan, S. (1989) 'The Effects of Management Buyouts on operating performance and value', Journal of Financial Economics, 24: 217-54

La Porta, R., Lopez-De-Silanes, F., Shleifer, A. and Vishny, R. (1997) 'Legal Determinants of External Finance', Journal of Finance, 3(52), 1131-50.

Long, W.F. and Ravenscraft, D.J. (1993) 'LBOs, debt and R\&D intensity', Strategic Management Journal (Summer Special Issue), 14: 119-35.

Oliver, C. (1991) 'Strategic Responses to Institutional Processes', Academy of Management Review, 1(16): 145-79.

Oliver, C. (1997) 'Sustainable Competitive Advantage: Combining Institutional and Resource-based Views', Strategic Management Journal, 18(9): 697-713.

Paauwe, J. and Boselie, P. (2003) 'Challenging 'strategic HRM' and the relevance of the institutional setting', Human Resource Management Journal, 3(13): 56-70.

Pendleton, A., Wilson, N. and Wright, M. (1998) 'The Perceptions and Effects of Share Ownership: Empirical Evidence from Employee Buy-outs', British Journal of Industrial Relations, 1(36): 99-124.

Phan, P. and Hill, C. (1995) 'Organisational restructuring and economic performance in leveraged buyouts: an ex post study', Academy of Management Journal, 38: 704-39.

Phillips, G. (1995) 'Increased debt and industry product markets: An empirical analysis', Journal of Financial Economics, 37: 189-238

Ramsay, H., Scholarios, D., and Harley, B. (2000) 'Employees and high-performance work systems: Testing inside the black box', British Journal of Industrial Relations, 4(38): 501.

Robbie, K. and Wright, M. (1996) 'Local authorities, Compulsory Competitive Tendering and Buy-outs', Local Government Studies, 1(22): 127-46. 
Sisson, K., and Marginson, P. (1995) 'Management: Systems, Structures and Strategy.' In: Edwards, P. (ed) Industrial Relations: Theory and Practice in Britain. Oxford: Blackwell: 89-122.

Thompson, S. and Wright, M. (1995) 'Corporate governance: The role of restructuring transactions.' Economic Journal, 105(430): 690-703

Thompson, R.S., Wright, M. and Robbie, K. (1992) 'Management equity ownership, debt and performance: some evidence from UK management buyouts'. Scottish Journal of Political Economy, 39(4): 413-30.

Tolbert, P.S., and Zucker, L.G. (1983) 'Institutional Sources of Change in the Formal Structure of Organisations: The Diffusion of Civil Service Reform', Administrative Science Quarterly, 28: 22-39

Van Neerven, T., Bruining, J., and Paauwe, J. (1996) 'Managing Without Traditional Owners'. In: Flood, P.C., Gannon, M.J., and Paauwe, J. (eds) Managing Without Traditional Methods. Wokingham: Addison-Wesley:105-46.

Visser, J. (1998) 'The Netherlands: The Return of Responsive Corporatism'. In: Ferner, A. and Hyman, R. (eds) Changing Industrial Relations in Europe. Oxford: Blackwell: 283-314.

Visser, J. (2003) ‘Arbeidsverhoudingen na de kanteling'. In: Nagelkerke, A.G. and de Nijs, W.F. (eds) (2003) Sturen in het laagland: Over continuïteit en verandering van de Nederlandse arbeidsverhoudingen. Delft: Eburon.

Visser, J., and Hemerijck, A. (1997) 'A Dutch Miracle' Job Growth, Welfare Reform and Corporatism in the Netherlands. Amsterdam: Amsterdam University Press.

Wood, S. and Albanese, M.T. (1995) 'Can We Speak of a High Commitment Management on the Shop Floor?', Journal of Management Studies, 32: 215-47.

Wright, M., Coyne, J., and Lockley, H. (1984) 'Management Buy-outs and Trade Unions: Dispelling the Myths', Industrial Relations Journal, 2(15): 45-52.

Wright, M., and Coyne, J. (1985) Management Buy-outs. London: Croom Helm.

Wright, M., Thompson, S. and Robbie, K. (1989) 'Privatization via Management and Employee Buy-outs', Annals of Public and Cooperative Economics, 4(60): 399-430.

Wright, M., Chiplin, B., Thompson, S., and Robbie, K. (1990) 'Management Buy-outs, Trade Unions and Employee Ownership', Industrial Relations Journal, 2(21): 13646. 
Wright, M., Thompson, S., and Robbie, K. (1992) 'Venture Capital and Management-led Leveraged Buy-outs: The European Perspective', Journal of Business Venturing, 7: 47-71

Wright, M., Hoskisson, R.E., and Busenitz, L.W. (2001) 'Firm Rebirth: Buy-outs as Facilitators of Strategic Growth and Entrepreneurship', Academy of Management Executive, 1(15): 111-25.

Wright, M., Hoskisson, R.E., Busenitz, L.W. and Dial, J. (2000) 'Entrepreneurial Growth Through Privatization: The Upside of Management Buy-outs', Academy of Management Review, 3(25): 591-601.

Zahra, S.A. (1995) 'Corporate Entrepreneurship and Financial Performance: The Case of Management Leveraged Buy-outs', Journal of Business Venturing, 10: 225-47.

Zucker, L.G. (1983) 'Organisations as Institutions'. In: Bacharach, S.B. (ed) Research in the Sociology of Organisations: 1-47. Greenwhich, CN: Jai Press. 
Table 1: HR policies reported in buy-outs in the UK and the Netherlands (\% reporting)

\begin{tabular}{|c|c|c|c|}
\hline HR Policy & UK & NL & $\begin{array}{l}\text { z-test of } \\
\text { proportions }\end{array}$ \\
\hline \multicolumn{4}{|l|}{ Pay systems } \\
\hline Own shares under share-ownership/share option schemes & 28 & 33 & 1.09 \\
\hline Receive merit payments & 72 & 53 & $2.38 * *$ \\
\hline Performance appraisal & 77 & 90 & $1.91+$ \\
\hline Profit-related pay & 60 & 80 & $2.45^{* *}$ \\
\hline \multicolumn{4}{|l|}{ Employee involvement methods } \\
\hline Daily 'walk around' workplace by senior manager & 88 & 87 & 0.18 \\
\hline Suggestion schemes & 44 & 27 & $2.03 * *$ \\
\hline Newsletters/ staff bulletins & 61 & 76 & $1.84+$ \\
\hline Attitude survey & 27 & 31 & 0.52 \\
\hline Regular social functions & 58 & 47 & 1.30 \\
\hline Team briefing & 64 & 84 & $2.53 * *$ \\
\hline Employees involved in setting performance targets & 40 & 49 & 1.07 \\
\hline Information given to employees on company performance & 76 & 67 & 1.20 \\
\hline Problem solving groups (quality circles) & 32 & 75 & $5.10 * * *$ \\
\hline \multicolumn{4}{|l|}{ Other high commitment management practices } \\
\hline Most employees work in formally designated teams & 49 & 40 & 1.06 \\
\hline Guaranteed job security or no redundancies policy & 2 & 16 & $3.66^{* * *}$ \\
\hline Most employees have minimum five days training per year & 4 & 24 & $4.15^{* * *}$ \\
\hline Most employees trained to do jobs other than their own & 43 & 35 & 0.95 \\
\hline Employees decide how work is done & 42 & 56 & $1.65+$ \\
\hline $\begin{array}{l}\text { Temporary staff only used to protect job security of } \\
\text { core employees }\end{array}$ & 26 & 29 & 0.40 \\
\hline Internal promotion preferred & 47 & 58 & 1.29 \\
\hline
\end{tabular}


Table 2 Changes in Employee Relations

\begin{tabular}{|c|c|c|c|c|}
\hline $\begin{array}{l}\text { Which issues have changed } \\
\text { as a direct result of the buy- } \\
\text { out: }\end{array}$ & $\begin{array}{c}\text { Mean UK } \\
\text { (s.d.) }\end{array}$ & $\begin{array}{c}\text { Mean NL } \\
\text { (s.d.) }\end{array}$ & $\begin{array}{c}\text { T test for } \\
\text { Equality of Means } \\
(\mathrm{NL}=\mathbf{1}, \mathrm{UK}=\mathbf{0})\end{array}$ & $\begin{array}{c}\text { Levene's F Test } \\
\text { For Equality of } \\
\text { Variances }\end{array}$ \\
\hline \multicolumn{5}{|l|}{$\begin{array}{l}\text { Employment } \\
\text { (3-point scale) }\end{array}$} \\
\hline Total number of employees & $\begin{array}{r}2.39 \\
(0.82)\end{array}$ & $\begin{array}{l}2.47 \\
(0.79)\end{array}$ & 0.54 & 0.75 \\
\hline \multicolumn{5}{|l|}{$\begin{array}{l}\text { HR management issues } \\
(5 \text {-point scale })\end{array}$} \\
\hline Importance of HRM issues & $\begin{array}{c}3.81 \\
(0.96)\end{array}$ & $\begin{array}{l}3.47 \\
(0.67)\end{array}$ & $-2.20^{*}$ & $16.87 * * *$ \\
\hline $\begin{array}{l}\text { Resources devoted to } \\
\text { managing employees }\end{array}$ & $\begin{array}{r}3.63 \\
(1.02)\end{array}$ & $\begin{array}{r}3.42 \\
(0.54)\end{array}$ & -1.33 & $33.01 * * *$ \\
\hline $\begin{array}{l}\text { The amount of training } \\
\text { employees receive }\end{array}$ & $\begin{array}{l}3.83 \\
(0.98)\end{array}$ & $\begin{array}{r}3.20 \\
(0.55)\end{array}$ & $-4.12 * * *$ & $35.23 * * *$ \\
\hline $\begin{array}{l}\text { The flexibility shown by } \\
\text { employees }\end{array}$ & $\begin{array}{r}3.92 \\
(0.94)\end{array}$ & $\begin{array}{l}3.50 \\
(0.63)\end{array}$ & $-2.80 * *$ & $19.92 * * *$ \\
\hline $\begin{array}{l}\text { Workers responsibility for } \\
\text { their jobs }\end{array}$ & $\begin{array}{l}4.05 \\
(0.90)\end{array}$ & $\begin{array}{c}3.73 \\
(0.72)\end{array}$ & $-2.15^{*}$ & $8.39^{* *}$ \\
\hline $\begin{array}{l}\text { The total number of } \\
\text { employees working in teams }\end{array}$ & $\begin{array}{l}3.78 \\
(0.95)\end{array}$ & $\begin{array}{r}3.40 \\
(0.58)\end{array}$ & $-2.56^{*}$ & $44.61 * * *$ \\
\hline Avoiding lay-offs & $\begin{array}{r}3.12 \\
(0.78)\end{array}$ & $\begin{array}{r}3.11 \\
(0.71)\end{array}$ & -0.03 & 0.02 \\
\hline The use of internal promotion & $\begin{array}{l}3.48 \\
(0.88)\end{array}$ & $\begin{array}{l}3.27 \\
(0.62)\end{array}$ & -1.51 & $11.31 * *$ \\
\hline $\begin{array}{l}\text { Use of temporary workers } \\
\text { only to cover shortages }\end{array}$ & $\begin{array}{r}3.25 \\
(0.83)\end{array}$ & $\begin{array}{r}2.86 \\
(0.93)\end{array}$ & $-2.61 * *$ & 1.21 \\
\hline $\begin{array}{l}\text { The level of trust between } \\
\text { managers and workers }\end{array}$ & $\begin{array}{l}3.94 \\
(0.98)\end{array}$ & $\begin{array}{r}3.62 \\
(0.78)\end{array}$ & -1.97 & $6.71 *$ \\
\hline $\begin{array}{l}\text { The similarity of terms and } \\
\text { conditions between managers } \\
\text { and non-managers }\end{array}$ & $\begin{array}{c}3.39 \\
(0.87)\end{array}$ & $\begin{array}{c}3.22 \\
(0.47)\end{array}$ & -1.23 & $16.55^{* * *}$ \\
\hline \multicolumn{5}{|l|}{$\begin{array}{l}\text { Payment \& rewards (1) } \\
\text { (5-point scale) }\end{array}$} \\
\hline $\begin{array}{l}\text { The number of staff whose } \\
\text { performance is appraised on } \\
\text { an annual or bi-annual basis }\end{array}$ & $\begin{array}{c}3.65 \\
(0.87)\end{array}$ & $\begin{array}{c}3.47 \\
(0.69)\end{array}$ & -1.26 & $9.31 * *$ \\
\hline The number of staff receiving & 3.69 & 3.27 & $-2.81 * *$ & $18.41^{* * *}$ \\
\hline
\end{tabular}




\begin{tabular}{|c|c|c|c|c|}
\hline merit pay & $(0.91)$ & $(0.73)$ & & \\
\hline $\begin{array}{l}\text { The percentage of non- } \\
\text { managerial employees } \\
\text { owning shares in the } \\
\text { company }\end{array}$ & $\begin{array}{r}3.27 \\
(0.81)\end{array}$ & $\begin{array}{r}3.33 \\
(0.92)\end{array}$ & 0.36 & 0.80 \\
\hline $\begin{array}{l}\text { Degree of employee } \\
\text { involvement }\end{array}$ & $\begin{array}{l}4.07 \\
(0.91)\end{array}$ & $\begin{array}{r}3.80 \\
(0.69)\end{array}$ & -1.82 & $12.36 * * *$ \\
\hline \multicolumn{5}{|l|}{$\begin{array}{l}\text { Payment \& rewards (2) } \\
\text { (3-points scale) }\end{array}$} \\
\hline Earnings of directors & $\begin{array}{r}2.48 \\
(0.69)\end{array}$ & $\begin{array}{c}2.29 \\
(0.66)\end{array}$ & $-1.66+$ & 0.75 \\
\hline Earnings of middle managers & $\begin{array}{r}2.70 \\
(0.47)\end{array}$ & $\begin{array}{c}2.68 \\
(0.47)\end{array}$ & -0.24 & 0.10 \\
\hline Earnings of line managers & $\begin{array}{c}2.57 \\
(0.51)\end{array}$ & $\begin{array}{c}2.41 \\
(0.55)\end{array}$ & $-1.69+$ & 0.62 \\
\hline $\begin{array}{l}\text { Earnings of non-managerial } \\
\text { employees }\end{array}$ & $\begin{array}{r}2.54 \\
(0.54)\end{array}$ & $\begin{array}{c}2.51 \\
(0.55)\end{array}$ & -0.30 & 0.04 \\
\hline
\end{tabular}

Sig. levels: $+\mathrm{p}<0.10 \quad * \mathrm{p}<0.05 \quad * * \mathrm{p}<0.01 \quad * * * \mathrm{p}<0.001$

Notes: Scales were as follows:

Employment (3-point scale): 1 =gone down, 2 =about the same, 3 = gone up.

HR management issues (5-point scale): 1 =decreased a lot; 2 = decreased; 3 = stayed the same; 4 =increased; $5=$ increased a lot.

Payment \& rewards (1)(5-point scale): 1 =decreased a lot, $2=$ decreased, $3=$ stayed the same, $4=$ increased, $5=$ increased a lot.

Payment \& rewards (2)(3-point scale): 1 =gone down, 2 =about the same, 3 = gone up. 
Table 3: Recognition of trade unions for collective bargaining

\begin{tabular}{|l|l|l|l|l|}
\hline & $\begin{array}{l}\text { Total } \\
\text { Sample }\end{array}$ & UK & NL & $\begin{array}{l}\text { T test for Equality of } \\
\text { Means (NL=1, UK=0) }\end{array}$ \\
\hline Before buy-out & $41 \%$ & $34 \%$ & $62 \%$ & $3.39^{* *}$ \\
\hline Immediately after: & $35 \%$ & $29 \%$ & $56 \%$ & $3.34^{* *}$ \\
\hline Currently: & $41 \%$ & $34 \%$ & $60 \%$ & $3.11^{*}$ \\
\hline
\end{tabular}

Table 4: General attitudes of managers towards trade union membership among employees at the establishment

\begin{tabular}{|l|l|l|l|l|}
\hline & $\begin{array}{l}\text { Total } \\
\text { Sample }\end{array}$ & UK & NL & $\begin{array}{l}\text { Test for Equality of } \\
\text { Means (NL=1, UK=0) }\end{array}$ \\
\hline $\begin{array}{l}\text { In favour of } \\
\text { membership: }\end{array}$ & $9 \%$ & $10 \%$ & $6 \%$ & -0.61 \\
\hline $\begin{array}{l}\text { Neutral to } \\
\text { membership: } 60 \%\end{array}$ & $50 \%$ & $88 \%$ & $4.89 * * *$ \\
\hline $\begin{array}{l}\text { Not in favour of } \\
\text { membership: }\end{array}$ & $29 \%$ & $40 \%$ & $6 \%$ & $-3.90 * * *$ \\
\hline
\end{tabular}




\section{Publications in the ERIM Report Series Research* in Management}

\section{ERIM Research Program: "Organizing for Performance"}

\section{4}

Learning And Governance In Inter-Firm Relations

Bart Nooteboom

ERS-2004-003-ORG

http://hdl.handle.net/1765/1122

Organisational Learning And Multinational Strategy

Bart Nooteboom

ERS-2004-004-ORG

$\underline{\text { http://hdl.handle.net/1765/1123 }}$

Density And Strength Of Ties In Innovation Networks: A Competence And Governance View Bart Nooteboom and Victor A. Gilsing

ERS-2004-005-ORG

http://hdl.handle.net/1765/1124

Innovation, learning and cluster dynamics

Bart Nooteboom

ERS-2004-006-ORG

http://hdl.handle.net/1765/1125

Empirical Tests Of Optimal Cognitive Distance

Stefan Wuyts, Massimo G. Colombo, Shantanu Dutta, and Bart Nooteboom

ERS-2004-007-ORG

http://hdl.handle.net/1765/1126

Entrepreneurship in Transition: Searching for governance in China's new private sector Barbara Krug and Hans Hendrischke

ERS-2004-008-ORG

http://hdl.handle.net/1765/1128

Exploring Emotional Competence: Its effects on coping, social capital, and performance of salespeople Willem Verbeke, Frank Belschak and Richard P. Bagozzi ERS-2004-014-ORG

http://hdl.handle.net/1765/1174

* A complete overview of the ERIM Report Series Research in Management: https://ep.eur.n//handle/1765/1

ERIM Research Programs:

LIS Business Processes, Logistics and Information Systems

ORG Organizing for Performance

MKT Marketing

F\&A Finance and Accounting

STR Strategy and Entrepreneurship 